\title{
Communication
}

[Comunicação]

\section{Correlating mesophilic counts to the pseudo-CMP content of raw milk}

\author{
[Correlação entre contagem de mesófilos e índice de Pseudo-CMP em leite cru] \\ N.K.L. Raymundo ${ }^{1}$, H. Daguer ${ }^{2}$, S.C. Osaki ${ }^{1}$, L.S. Bersot ${ }^{1} *$ \\ ${ }^{1}$ Universidade Federal do Paraná - Palotina, PR \\ ${ }^{2}$ Ministério da Agricultura, Pecuária e Abastecimento - São José, SC
}

Trading uninspected raw milk directly to consumers is prohibited in Brazil, contrary to other countries in Europe, such as Italy, where sales of raw milk are permitted since 2004 (Giacometti et al., 2012). Adulterations, such as the addition of whey, still are among the main problems related to milk. One of the most popular methods for the detection of whey is based on the casein macropeptide (CMP). The addition of $1 \%$ whey solids to milk usually yields a concentration of $6 \mathrm{pg} \mathrm{CMP} / \mathrm{mL}$ (Riel \& Olieman, 1995). On the other hand, pseudo-CMP (p-CMP) can be produced by the cleavage of casein by bacterial proteases. Since CMP and pCMP differ by a single amino acid, their differentiation is required to indicate clearly how adulterated milk is or if it is due to intense proteolysis resulting from poor bacterial quality (Motta et al., 2014; Riel \& Olieman, 1995).

Raw milk may present low microbiological quality, as determined by standard plate counts of mesophilic microorganisms, also called as total bacterial count (TBC), which has been settled as the reference method to determine milk quality in Brazil (Bersot et al., 2010). Given that direct trade of raw milk to consumers is still commonly performed in Brazil, the possibility of adulterations, and the microbiological quality of this product were assessed in this work. Thus, the main goals of this work were to quantify the casein macropeptide (CMP), as well as to differentiate CMP (due to adulteration with whey) from pseudo-CMP (due to bacterial proteolysis) in raw milk samples, and to correlate total bacterial counts and the CMP concentration.

CMP (91.3\% of purity) was obtained from Davisco Foods (Eden Prairie, MN, USA).

Recebido em 18 de maio de 2017

Aceito em 1 de fevereiro de 2018

*Autor para correspondência (corresponding author)

E-mail: lucianobersot@ufpr.br.
Acetonitrile HPLC grade (ACN) and acetic acid were obtained from J.T. Baker Chemical Co. (Phillipsburg, NJ, USA), trifluoroacetic acid (TFA) and glycine were obtained from Vetec (Sigma-Aldrich Co. LLC, Duque de Caxias, Brazil) and trichloroacetic acid (TCA) was from Merck KGaA (Darmstadt, Germany). Pepsin A (EC 3.4.23.1), obtained from swine gastric mucous, and formic acid were supplied by Sigma-Aldrich Chemie GmbH (Taufkirchen, Germany). The synthetic peptides MAIPPKKNQDKTEIPTINT and AIPPKKNQDKTEIPTINT were obtained from Mimotopes Pty Ltd. (Notting Hill, Australia), with purity of $96.0 \%$ and $95.0 \%$, respectively.

Uninspected raw milk samples were obtained from different households in five cities of relevant dairy production in the state of Paraná, southern Brazil. The samples $(n=46)$ were transported and kept under refrigeration until analysis. Samples for the analysis of CMP were immediately frozen and kept at $-18^{\circ} \mathrm{C}$ until analysis.

Samples were diluted in $0.85 \%$ saline solution, and $1 \mathrm{~mL}$ of each dilution was used for plate count agar (Merck KGaA, Darmstadt, Germany) pour plates in sterile Petri dishes. The dilutions employed in this study were $10^{-2}$ to $10^{-5}$. Plates were incubated at $35-37^{\circ} \mathrm{C}$ for $48 \mathrm{~h}$. Readings were carried out in a plate counter and expressed in $\mathrm{CFU} / \mathrm{mL}$ of sample, according to the ISO 4833 method (International..., 2003).

CMP has been quantitated by high performance liquid chromatography (HPLC) in accordance to MAPA (Brasil, 2010). Briefly, samples of milk were precipitated with trichloroacetic acid $24 \%$, followed by a rest period for sedimentation and 
filtration, and analyzed on an Alliance 2695 pump (Waters Corporation, Milford, MA, USA) in isocratic mode, with phosphate buffer ( $\mathrm{pH}$ 6.4) as mobile phase. Chromatographic separation was carried out using gel filtration columns (D55122 Mainz, SI Analytics GmbH; $250 \mathrm{x}$ $9.4 \mathrm{~mm}^{2}$; particle size from 4 to $4.5 \mu \mathrm{m}$ ), followed by diode-array detection at $205 \mathrm{~nm}$. Matrixmatched analytical curves were prepared in the range of $15-100 \mathrm{mg} / \mathrm{L}$ for samples quantitation. Analyses were carried out in duplicate, and results were expressed as arithmetic means in $\mathrm{mg} / \mathrm{L}$.

Milk samples that yielded results over $30 \mathrm{mg} / \mathrm{L}$ of CMP underwent the peptide identification by LC-MS/MS according to Motta et al. (2014). Samples of milk were submitted to precipitation with trichloroacetic acid $24 \%$, followed by a rest period and filtration. Then, $200 \mu \mathrm{L}$ of the supernatant were transferred to vials; after that, $200 \mu \mathrm{L}$ glycine $1 \mathrm{~mol} / \mathrm{L}, 550 \mu \mathrm{L}$ of ultrapure water and $50 \mu \mathrm{L}$ pepsin $10 \mu \mathrm{g} / \mathrm{mL}$ were added to each vial, which were incubated at $37^{\circ} \mathrm{C}$ for at least $8 \mathrm{~h}$. Analysis of digestion products was carried out by injection in the API 5000 mass spectrometer with electrospray ionization in positive mode (Sciex, Foster City, CA, USA), coupled to a 1100 Series liquid chromatography system (Agilent Technologies, Inc., Santa Clara, CA, USA). Chromatographic separation was achieved in a PLRP-S (polystyrenedivinylbenzene) column, $150 \times 4.6 \mathrm{~mm}^{2}, 300 \AA$ (Polymer Technologies, Varian). For CMP, the transitions $(\mathrm{m} / \mathrm{z}) 713.8>798.0,713.8>953.7$ and $713.8>897.2$ were chosen. The $713.8>$ 798.0 transition was the most intense and was selected for quantitative purpose. For p-CMP, the transitions $(\mathrm{m} / \mathrm{z}) 670.0>732.8,670.0>888.5$ and $670.0>913.0$ were monitored. Matrixmatched analytical curves were prepared in the range of $5-90 \mathrm{mg} / \mathrm{L}$ for samples quantitation.

The correlation $(\mathrm{P}<0.001)$ between the results of Total Bacterial Count (TBC) and CMP index was determined using the SAS 9.2 software (SAS Institute, Cary, NC, USA).

Mean TBC was 5,200,000CFU/mL, which is much higher than the regulatory limit of $100,000 \mathrm{CFU} / \mathrm{mL}$ settled by current Brazilian regulation (Brasil, 2011). Besides, $60.9 \%$ of the samples were non-compliant with official regulations. The chromatographic analysis of milk samples led to typical size-exclusion chromatograms, where the elution of the analyte occurred around 10min (Figure 1). Ten samples (21.7\%) were non-compliant with the CMP official regulation (maximum $30 \mathrm{mg} / \mathrm{L}$ ) (Table 1). Mean concentration of CMP was $57.18 \mathrm{mg} / \mathrm{L}$. Moreover, all samples were non-compliant to TBC regulatory limit. Milk samples that were non-compliant to the maximum CMP regulatory level of $30 \mathrm{mg} / \mathrm{L}$ settled by Brazilian regulation (Brasil, 2006) were all positive for p-CMP at LC-MS/MS confirmation. The reliability of the CMP analysis of milk is only possible soon after packaging, and sample freezing is requested if immediate analysis is not possible (Villanoeva et al., 2014).

High TBC in the samples that showed noncompliance with the regulations presented a positive correlation $(\mathrm{P}=0.0067)$ with the respective CMP levels, indicating a directly proportional relationship between CMP index and TBC ( $r=0,50061)$. Considering all samples of uninspected raw milk analyzed $(n=46)$, no matter their compliance with the official regulations considered in this study, there was a positive correlation $(\mathrm{P}<0.0001)$ between TBC and the concentration of $\mathrm{p}-\mathrm{CMP}$ index. Thus, a high correlation between TBC and the existence of proteolytic bacteria could be concluded.

Values over 30mg/L CMP may indicate either intentional addition of whey or changes in raw milk caused by proteolytic enzymes produced by high loads of contaminant microorganisms during the refrigerated storage (HantisisZacharov \& Halpern, 2007; Motta et al., 2014). An important requirement of any assessment of CMP in milk is the capability to differentiate CMP from $\mathrm{p}$-CMP, to prevent falsely adulterated results (Riel \& Olieman, 1995). CMP is a phosphorylated hydrophilic peptide, with three genetic variations (Smith et al. 2002). Due to the presence of a high degree of glycosylation sites, CMP is also known as glycomacropeptide (GMP). Since the multiple reaction monitoring (MRM) was used to monitor products of CMP digestion with pepsin, glycosylation and phosphorylation sites and genetic variations did not interfered the LC-MS/MS analysis, because they remained in non-monitored fragments (Motta et al., 2014). 


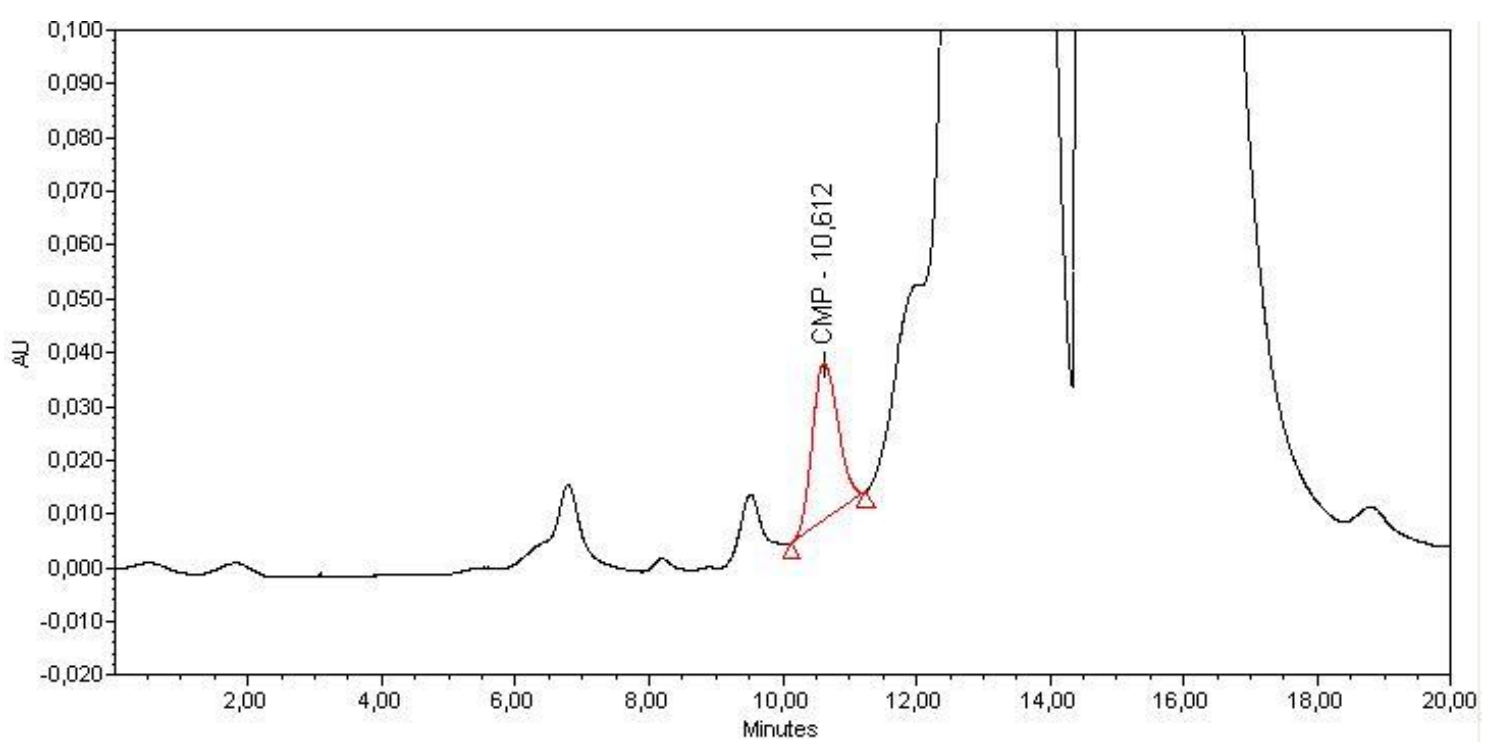

Figure 1. Size-exclusion chromatogram with diode-array detection at $205 \mathrm{~nm}$ for the analysis of casein macropeptide (CMP) in raw milk.

Table 1. Casein macropeptide (CMP) size-exclusion chromatography (diode array detection at 205nm) results of non-compliant raw milk samples and respective total bacterial counts $(n=10)$

\begin{tabular}{ccc} 
Sample number & $\begin{array}{c}\text { CMP* } \\
(\mathrm{mg} / \mathrm{L})\end{array}$ & $\begin{array}{c}\text { TBC** } \\
(\mathrm{CFU} / \mathrm{mL})\end{array}$ \\
\hline 2 & 33.35 & $5,600,000$ \\
4 & 49.16 & $24,000,000$ \\
5 & 47.93 & $18,000,000$ \\
14 & 111.50 & $170,000,000$ \\
19 & 59.49 & $50,000,000$ \\
24 & 73.98 & $8,100,000$ \\
25 & 49.81 & $13,000,000$ \\
43 & 81.77 & $2,800,000$ \\
45 & 32.58 & $3,400,000$ \\
46 & 32.22 & $3,500,000$ \\
\hline
\end{tabular}

Brazilian regulatory limits: ${ }^{*} \mathrm{CMP}<30 \mathrm{mg} / \mathrm{L} ;{ }^{* *} \mathrm{TBC}$ (total bacteria count) $<100,000 \mathrm{CFU} / \mathrm{mL}$.

The high CMP levels observed in milk were, in fact, of microbial origin. Therefore, TBC continues to be the most practical and fast method for the estimation of milk bacterial load. It can be inferred that the high P-CMP concentrations were due to the action of bacterial enzymes on milk casein, instead of the fraud by addition of whey. High microbial loads are well known to increase the concentration of p-CMP, being related to inadequate hygiene procedures and/or storage at inadequate temperatures (Bremer et al., 2008). Psychrotrophic bacteria, especially Pseudomonas sp., produce lipases and proteases. Pseudomonas fluorescens is the most frequent psychrotrophic bacteria found in milk, featuring the cleavage of k-casein in a very similar way to chymosin in the cheese making process (Recio et al., 1996).

Our results also reinforce the need for hygienic practices during milking and milk storage to ensure proper quality. Good manufacturing procedures must not being adequately followed in the trade of raw milk to consumers. In conclusion, CMP quantitation and confirmation of p-CMP did not evidence the occurrence of adulteration of uninspected milk by the addition of whey. Therefore, screening milk for CMP by size-exclusion chromatography alone cannot be considered determinant for the confirmation of 
adulteration by the addition of whey. The use of liquid chromatography coupled to mass spectrometry plays an essential role in this case. The p-CMP concentrations found in this study were positively correlated to mesophilic microbial load. Thus, TBC could be a reliable indirect indicator of the presence of proteolytic microorganisms and is bothfaster and easier to perform than the direct quantitation of proteolytic microorganisms.

\section{ACKNOWLEDGMENTS}

We acknowledge Brazilian Federal Agency for the Support and Evaluation of Graduate Education (CAPES) for funding this research with graduate fellowship for Nelson K.L. Raymundo. We are also grateful to Tanara M.C. Motta and Fabiano Barreto (LANAGRO/RS) for performing the CMP identification.

Keywords: chromatography, correlation, mesophilic counts, p-CMP, uninspected milk

\section{RESUMO}

A presente comunicação objetivou avaliar a quantificação do caseínomacropeptídeo (CMP), bem como diferenciá-lo (devido à adulteração com soro) do pseudo-CMP (devido à proteólise bacteriana) em amostras de leite cru coletadas nos domicílios do sul do Brasil. Os resultados reforçam a necessidade de práticas higiênicas durante a ordenha e estocagem do leite. As amostras de leite estudadas não estavam adulteradas por adição de soro, mostrando que a análise por cromatografia de exclusão por tamanho deve ser complementada a fim de revelar a identidade do peptídeo (CMP ou pseudo-CMP). A contagem bacteriana total (TBC) também se mostrou útil como indicador da contaminação do leite por microorganismos proteolíticos, uma vez que uma relação diretamente proporcional entre TBC e pseudo-CMP foi estabelecida.

Palavras-chave: cromatografia, correlação, contagem de mesófilos, p-CMP, leite sem inspeção

\section{REFERENCES}

BERSOT, L.S.; DAGUER, H.; MAZIERO, M.T. et al. Raw milk trade: profile of the consumers and microbiological and physicochemical characterization of the product and in Palotina PR Region. Rev. Inst. Latic. Cândido Tostes, v.65, p.3-8, 2010.

BRASIL. Ministério da Agricultura, Pecuária e Abastecimento. Instrução Normativa $n^{\circ} 69$. Critério de avaliação da qualidade do leite in natura, concentrado e em pó, reconstituídos, com base no método analítico oficial físico-químico denominado Índice de CMP. Diário Oficial da União, Brasília, 15 dez. 2006.

BRASIL. Ministério da Agricultura, Pecuária e Abastecimento. Instrução Normativa $n^{\circ} 7$. Método Oficial de Determinação de CMP (caseinomacropeptídeo) por HPLC, eletroforese capilar e espectrometria de massas em leite, em apresentações integrais, semidesnatadas e desnatadas, tratados por processos de UHT ou pasteurização. Diário Oficial da Uni Diário Oficial da União, Brasília, 03 mar. 2010.
BRASIL. Ministério da Agricultura, Pecuária e Abastecimento. Instrução Normativa $n^{\circ} 62$. Regulamento técnico de produção, identidade e qualidade de leite tipo a, leite cru refrigerado, leite pasteurizado e leite cru refrigerado e seu transporte a granel. Diário Oficial da União, Brasília, 30 dez. 2011.

BREMER, M.G.; KEMMERS-VONCKEN, A.E.; BOERS, E.A.; FRANKHUIZEN, R.; HAASNOOT, W. Enzyme-linked immunosorbent assay for the detection of bovine rennet whey powder in milk powder and buttermilk powder. Int. Dairy J., v.18, p.294302, 2008.

GIACOMETTI, F.; SERRAINO, A.; FINAZZI, G. et al. Sale of raw milk in northern italy: food safety implications and comparison of different analytical methodologies for detection of foodborne pathogens. Foodborne Pathog. Dis., v.9, p.293-297, 2012.

HANTISIS-ZACHAROV, E.; HALPERN, M. Culturable psychrotrophic bacterial communities in raw milk and their proteolytic and lipolytic traits. Appl. Environ. Microbiol., v.73, p.71627168, 2007. 
INTERNATIONAL Organization for Standardization. ISO 4833:2003 Microbiology of food and animal feeding stuffs-Horizontal method for the enumeration of microorganisms: colony-count technique at $30^{\circ} \mathrm{C}$. Geneva: ISO, 2003.

MOTTA, T.C.; HOFF, R.B.; BARRETO, F. et al. Detection and confirmation of milk adulteration with cheese whey using proteomiclike sample preparation and liquid chromatography-electrospray-tandem mass spectrometry analysis. Talanta, v.120, p.498$505,2014$.

RECIO, I.; LÓPEZ-FANDIÑO, R.; OLANO, A.; OLIEMAN, C.; RAMOS, M. Study of the formation of caseinomacropeptides in stored ultra-high-temperature-treated milk by capillary electrophoresis. J. Agricult. Food Chem., v.44, p.3845-3848, 1996.
RIEL, J.V.; OLIEMAN, C. Determination of caseinomacropeptide with capillary zone electrophoresis and its application to the detection and estimation of rennet whey solids in milk and buttermilk powder. Electrophoresis, v.16, p.529-533, 1995.

SMITH, M.H.; EDWARDS, P.J.; PALMANO, K.P.; CREAMER, L.K. Structural features of bovine caseinomacropeptide $\mathrm{A}$ and $\mathrm{B}$ by $1 \mathrm{H}$ nuclear magnetic resonance spectroscopy. $J$. Dairy Res., v.69, p.85-94, 2002.

VILLANOEVA, C.N.B.C.; ANDRADE, E.H.P.; BAFFA JUNIOR, J.C. et al. Caseinomacropeptide index in UHT whole milk stored under different conditions of temperature and time. Arq. Bras. Med. Vet. Zootec., v.66, p.289-296, 2014. 